\title{
PENGARUH TERAPI KOMPRES HANGAT TERHADAP PENURUNAN NYERI SENDI OSTEOARTHRITIS PADA LANSIA DI POSYANDU LANSIA PUSKESMAS PANDIAN SUMENEP
}

Mujib Hannan, Program Studi IImu Keperawatan Universitas Wiraraja

e-mail: Mujib@wiraraja.ac.id

Emdat Suprayitno, Program Studi Profesi Ners Universitas Wiraraja

e-mail: emdats@yahoo.com

Hesti Yuliyana, Program Studi IImu Keperawatan Universitas Wiraraja

e-mail: hestiyuliana@gmail.com

\section{ABSTRACT}

Along with the aging process, the body will experience various health problems. One of them osteoartrisis which is a disease of bones and joints that occur due to aging process. The purpose of this study was to study the effect of warm water compress therapy on the reduction of osteoarthritis joint pain in elderly at posyandu elderly puskesmas Pandian Sumenep.

The type of research is Pre Experimental, where the population amounted to 40 people and the sample amounted to 32 people with elderly characteristics who experience osteoarthritis joint pain. Sampling technique used is Type Probability sampling that is Simple Random Sampling. Data collection methods used were interviews and questionnaires. Presentation of data using pie chart and characteristic distribution table with $T$ paired statistical test.

The results showed that more than half had osteoarthritis joint pain with moderate pain scale of 22 elderly (68.7\%). Based on the result of T paired test, there is influence between warm water compress therapy to decrease osteoarthritis joint pain in elderly $(\rho=0,000<\alpha=0,05)$.

Osteoarthritis pain in elderly in Puskesmas Pandian Sumenep mostly due to the activity of many or excess. Advice for health services to make warm compress therapy as a self-directed nursing intervention in treating joint pain patients with osteoarthritis.

\section{Keywords: Warm Compress, Osteoarthriti.}

\section{PENDAHULUAN}

Lanjut usia bukan suatu penyakit, namun merupakan tahap lanjut dari suatu proses kehidupan yang ditandai dengan penurunan kemampuan tubuh untuk beradaptasi dengan stress lingkungan (Pudjiastuti, 2003 dalam Ferry dan Makhfudli, 2009). Seiring dengan proses menua tersebut, tubuh akan mengalami berbagai masalah kesehatan atau yang biasa disebut sebagai penyakit degeneratif. Salah satunya penyakit osteoartrisis yang merupakan penyakit tulang dan sendi yang terjadi karena proses menua (Siti, 2008). Nyeri sebagai mekanisme proteksi bagi tubuh, timbul ketika jaringan sedang rusak, dan menyebabkan individu tersebut bereaksi untuk menghilangkan rasa nyeri (Andarmoro, 2013).

Data hasil Kementrian Kesehatan RI, jumlah lansia di Indonesia sebanyak 23,66 juta jiwa. Keluhan kesehatan yang sering terjadi yaitu rematik, asam urat, darah tinggi, dan diabetes dengan prevalensi 32,99\% (Susenas, 2012). Data lansia Dinas Kesehatan Kabupaten Sumenep tahun 2016, lansia yang mengalami nyeri sendi sebanyak
1077 orang, dengan lansia laki-laki sebanyak 447 orang dan lansia perempuan sebanyak 630 orang. Data lansia di posyandu lansia puskesmas Pandian Sumenep tahun 2017 jumlah lansia sebanyak 591 orang, dengan pra lansia (45 - 59 tahun) 256 orang dan lansia dan resti (60/80 tahun keatas) sebanyak 335 orang. Jumlah lansia yang mengalami nyeri sendi akibat osteoarthritis sebanyak 40 orang, diantaranya laki-laki sebanyak 16 orang dan perempuan sebanyak 24 orang. Prevalensi penyakit tersebut sebanyak $7 \%$ dari total lansia di seluruh posyandu lansia puskesmas Pandian Sumenep.

Sendi yang terserang terutama sendi penopang tubuh, yaitu lutut, tulang belakang, dan pangkal paha (panggul). Dapat terjadi pada salah satu sisi atau kedua-duanya, bisa pula beberapa sendi terserang sekaligus. Ada juga penderita yang mengalami pembengkakan sendi (merah, panas, nyeri) yang kadang-kadang disertai penumpukan cairan dalam sendi. Bila ini terjadi, cairan tersebut perlu disedot atau dikeluarkan oleh dokter. (Santoso dkk, 2009). Penanganan 
penyakit pada usia lanjut bersifat khusus. Hal itu dikarenakan penyakit pada usia lanjut biasanya tidak berdiri sendiri (multipatologi), fungsi organ tubuh sudah menurun, rentan terhadap penyakit atau stres, dan lebih sering memerlukan rehabilitasi yang tepat. Untuk mengurangi rasa nyeri perlu dilakukan pemanasan atau pendinginan. Pada prinsipnya, dengan rehabilitasi diharapkan penderita dapat melakukan aktivitas seharihari tanpa bantuan orang lain. (Muhith, dkk. 2016).

Strategi penatalaksanaan nyeri dengan menggunakan pendekatan manajemen farmakologis merupakan tindakan menurunkan respons nyeri tanpa sedikitpun menggunakan agen-agen farmakologi. Pemasangan kompres hangat biasanya dilakukan hanya setempat saja pada bagian tubuh tertentu. Dengan pemberian panas, pembuluh-pembuluh darah akan melebar sehingga memperbaiki peredaran darah di dalam jaringan tersebut. Dengan cara ini penyaluaran zat asam dan bahan makanan ke sel-sel diperbesar dan pembuangan dari zatzat yang dibuang akan diperbaiki. Aktivitas sel yang meningkat akan mengurangi rasa sakit/nyeri dan akan menunjang proses pemyembuhan luka dan proses peradangan (Stevens dkk, 2002).

Pemberian kompres hangat adalah memberikan rasa hangat pada klien dengan menggunakan cairan atau alat yang menimbulkan hangat pada bagian tubuh yang memerlukannya. Tujuannya adalah memperlancar sirkulasi darah, mengurangi rasa sakit, merangsang peristaltik usus, memperlancar pengeluaran getah radang (eksudat), memberikan rasa nyaman atau hangat dan tenang. Pemberian kompres panas dilakukan pada klien dengan perut kembung, klien yang mengalami radang, kekejangan otot (spasmus), adanya abses (bengkak) akibat suntikan, tubuh dengan abses atau hematom (Kusyati, 2006).

\section{METODE PENELITIAN}

Jenis penelitian ini merupakan Pre Eksperimental dengan rancang bangun penelitian One Group Pretest Postest. Populasi dalam penelitian ini adalah Semua lansia yang mengalami nyeri sendi osteoarthritis di posyandu lansia Puskesmas Pandian Sumenep dengan jumlah 40 orang lansia. Pada penelitian ini sampel di tentukan berdasarkan Kriteria inklusi yaitu: Lansia yang mengalami nyeri sendi osteoarthritis, Lansia yang tinggal menetap di wilayah kerja Puskesmas Pandian, Lansia yang bersedia diteliti. teknik sampling yang digunakan adalah Probability dengan Teknik Simple Random.

\section{HASIL PENELITIAN}

\begin{tabular}{|c|c|c|c|}
\hline No & Skala Nyeri & $F$ & $\%$ \\
\hline 1 & Nyeri Ringan & 3 & 9.4 \\
\hline 2 & Nyeri Sedang & 22 & 68.7 \\
\hline \multirow[t]{2}{*}{3} & Nyeri Berat & 7 & 21.9 \\
\hline & Total & 32 & 100 \\
\hline
\end{tabular}

Berdasarkan tabel 1 menunjukkan hasil bahwa sebagian besar skala nyeri responden sebelum diberikan terapi kompres hangat adalah nyeri sedang yaitu sebanyak 22 responden $(68,7 \%)$ dan sebagian kecil adalah nyeri ringan yaitu sebanyak 3 responden $(9,4 \%)$.

\section{Tabel 2 Distribusi Lansia Berdasarkan Skala Nyeri Sesudah Terapi Kompres Hangat}

\begin{tabular}{cccc}
\hline No & Skala Nyeri & $\mathrm{F}$ & $\%$ \\
\hline 1 & Nyeri Ringan & 18 & 56.3 \\
2 & Nyeri Sedang & 13 & 40.6 \\
3 & Nyeri Berat & 1 & 3.1 \\
\hline & Total & 32 & 100 \\
\hline
\end{tabular}

Berdasarkan tabel 2 menunjukkan hasil bahwa sbagian besar skala nyeri responden sesudah diberikan terapi kompres hangat adalah nyeri ringan yaitu sebanyak 18 responden $(56,3 \%)$ dan sebagian kecil adalah nyeri berat terkontrol yaitu sebanyak 1 responden $(3,1 \%)$.

\section{Distribusi Lansia Berdasarkan Skala Nyeri Sebelum dan Sesudah Terapi Kompres Hangat}

\begin{tabular}{cccccc}
\hline \multirow{2}{*}{ NO } & \multirow{2}{*}{ Keterangan } & \multicolumn{2}{c}{ Sebelum } & \multicolumn{2}{c}{ Sesudah } \\
\cline { 3 - 6 } & & $\mathrm{F}$ & $\%$ & $\mathrm{~F}$ & $\%$ \\
\hline 1 & Ringan & 3 & 9.4 & 18 & 56.3 \\
2 & Sedang & 22 & 68.7 & 13 & 40.6 \\
3 & Berat & 7 & 21.9 & 1 & 3.1 \\
\hline & Total & 32 & 100 & 32 & 100 \\
\hline
\end{tabular}

Berdasarkan tabel 5.3 menunjukkan hasil bahwa sebagian besar skala nyeri responden sebelum diberikan terapi kompres hangat adalah nyeri sedang yaitu sebanyak 22 responden $(68,7 \%)$ dan sebagian kecil adalah nyeri ringan yaitu sebanyak 3 
responden $(9,4 \%)$. Skala nyeri esudah diberikan terapi kompres hangat adalah nyeri ringan yaitu sebanyak 18 responden (56,3\%) dan sebagian kecil adalah nyeri berat terkontrol yaitu sebanyak 1 responden $(3,1 \%)$. Hasil uji statistik data dengan menggunakan Paired Simple T-Test di dapatkan p-value 0,00 , atau $0,00<(\alpha) 0,05$, maka HO ditolak dan $\mathrm{H} 1$ diterima artinya ada pengaruh terapi kompres hangat terhadap penurunan nyeri sendi osteoarthritis pada lansia di posyandu lansia puskesmas Pandian Sumenep.

\section{PEMBAHASAN}

\section{Skala Nyeri Sebelum Pada Lansia Dengan Osteoarthritis Diberikan Intervensi Terapi Kompres Hangat}

Berdasarkan hasil penelitian pre-test di Puskesmas Pandian Sumenep menunjukkan bahwa skala nyeri responden sebelum diberikan terapi kompres hangat dengan menggunakan alat ukur skala nyeri Verbal Descriptor Scale (VDS) didapatkan lansia yang mengalami nyeri dengan skala nyeri terbanyak adalah nyeri sedang sebanyak 22 lansia (68,7\%). Dengan responden perempuan sebanyak 26 responden $(81,2 \%)$ dan laki-laki sebanyak 6 responden $(18,8 \%)$. Dari data yang diperoleh bahwa lansia dengan osteoarthritis mengalami nyeri ringan sampai nyeri berat.

Menurut International Association for Study of Pain (IASP) (1986, dalam Triyana, 2012), nyeri merupakan sensori subjektif dan emosional yang tidak menyenangkan terkait dengan adanya kerusakan jaringan, baik secara aktual maupun potensial, atau menggambarkan kondisi terjadinya kerusakan. Sedangkan menurut definisi keperawatan nyeri sebagai suatu keadaan yang tidak menyenangkan akibat terjadinya rangsangan fisik maupun dari serabut saraf dalam tubuh ke otak yang diikuti oleh reaksi fisik (fisiologis) maupun emosional.

Perubahan tersebut berpengaruh pada kemunduran kesehatan fisik dan psikis yang pada akhirnya akan mempengaruhi pada ekonomi dan sosial lansia. Sehingga secara umum akan berpengaruh pada activity of daily living (Fatmah, 2010). Ada beberapa faktor yang mempengaruhi respon nyeri, yaitu usia, jenis kelamin, kebudayaan, makna nyeri, perhatian, kecemasan, keletihan, pengalaman sebelumnya, gaya koping, dukungan keluarga dan sosial. Lebih mudahnya osteoarthritis diartikan sebagai penyakit yang menyerang sendi, otot dan jaringan tubuh.
Setelah dilihat dari data di atas, maka hal ini sesuai dengan Rousseau and Goottlieb (2004) bahwa nyeri sendi banyak terjadi dan dikeluhkan oleh wanita lanjut usia dan sering muncul ketika wanita telah mengalami menopause. Menurut Kawiyana (2009), wanita yang telah menopause dan memasuki masa usia lanjut mengalami penurunan hormon estrogen sehingga terjadi ketidakseimbangan aktivitas osteoblas dan osteoklas yang mengakibatkan penurunan massa tulang trabekula dan kortikal sehingga menyebabkan tulang menjadi tipis, berongga, kekakuan sendi, pengelupasan rawan sendi dan sehingga akan muncul nyeri pada persendian. Jika nyeri tidak ditangani maka akan meningkatkan rasa ketidaknyamanan serta dapat mengganggu aktivitas wanita lanjut usia. Pada saat sebelum diberikan terapi kompres air hangat, wanita lansia merasakan nyeri dan kekakuan pada sendi yang nyeri terutama pada pagi hari. Teori dalam Riyanto (2011) menyebutkan bahwa terjadi penurunan aktivitas dan muncul kekakuan pada sendi saat pagi hari.

Dari hasil penelitian sebelumnya, penelitian yang dilakukan oleh Deu, dkk (2014) dengan judul "Gambaran Kejadian Nyeri Lutut Dengan Kecurigaan Osteoarthritis Lutut Pada Perawat Di Poliklinik Rawat Jalan Blu RSUP. Prof. DR. R. D. Kandou Manado" mengungkapkan osteoartritis merupakan penyakit sendi degeneratif yang berkaitan dengan kerusakan kartilago sendi. Osteoarthritis mengenai semua persendian dari servikal, thorakal, lumbal, panggul, lutut, pergelangan kaki, tangan sampai ke jari-jari, paling sering ditemukan pada sendi lutut karena sendi-sendi ini dapat pembebanan yang lebih besar dibanding sendi-sendi yang lain. Pasien osteoarthritis biasanya mengeluh nyeri pada waktu melakukan aktivitas atau jika ada pembebanan pada sendi yang terkena. Pada derajat yang lebih berat nyeri dapat dirasakan terus menerus sehingga sangat mengganggu mobilitas pasien.

Hasil penelitian sebelumnya, yang dilakukan oleh Masyhurrosyidi, dkk (2014) dengan judul "Pengaruh Kompres Hangat Rebusan Jahe Terhadap Tingkat Nyeri Subakut dan Kronis pada Lanjut Usia dengan Osteoarthtritis Lutut di Puskesmas Arjuna Kecamatan Klojen Malang Jawa Timur" mengungkapkan masalah fisiologis pada lanjut usia dengan osteoarthritis adalah nyeri. Nyeri pada osteoarthritis disebabkan oleh synovial dan degradasi kartilago berkaitan 
dengan degradasi kolagen dan proteoglikan oleh enzim autolitik seluler. Secara makroskopis tampak iregularitas pada permukaan tulang rawan yang dilanjutkan dengan ulserasi dan penurunan kandungan glikosaminoglikan yang terdiri dari kondroitin sulfat, keratin sulfat, dan asam hialuronat. Fibrilasi atau iregularitas terjadi karena mikrofraktur pada permukaan rawan sendi yang memiliki serabut saraf $C$ berdiameter kecil dan tidak bermielin-nocireseptor. Nocireseptor ini mampu melepaskan substansi $P$ lalu calcitonin gene related peptide (CGRP) menstimulasi respon nyeri dan inflamasi.

Sebagian besar lansia dengan osteoarthritis di Puskesmas Pandian Sumenep mengalami nyeri dikarenakan aktifitas yang banyak atau berlebih yang dapat menyebabkan ketegangan otot dan keletihan sehingga menyebabkan nyeri yang dapat mengganggu aktifitas lansia tersebut. Selain aktifitas, usia juga menjadi salah satu faktor yang mempengaruhi nyeri, semakin menua sering kali memiliki sumber nyeri lebih dari satu. Proses penuaan merupakan siklus kehidupan yang ditandai dengan tahapantahapan menurunnya berbagai fungsi organ tubuh, yang ditandai dengan semakin rentannya tubuh terhadap berbagai serangan penyakit yang dapat menyebabkan kematian misalnya pada sistem kardiovaskuler dan pembuluh darah, pernafasan, pencernaan, endokrin dan lain sebagainya. Awalnya nyeri dirasakan ketika beraktivitas, namun lamakelamaan ketika penyakit memberat nyeri bisa dirasakan saat istirahat maupun saat malam hari. Hal itu terlihat dari pemaparan lansia saat ditanya keluhan nyerinya. Skala Nyeri Pada Lansia Dengan Osteoarthritis Sesudah Diberikan Intervensi Terapi Kompres Hangat

Hasil pengukuran skala nyeri setelah diberikan intervensi terapi kompres hangat dengan menggunakan alat ukur skala nyeri Verbal Descriptor Scale (VDS) didapatkan lansia yang mengalami nyeri dengan skala nyeri terbanyak adalah nyeri ringan sebanyak 18 lansia (56,3\%).Lansia mengalami penurunan skala nyeri disebabkan karena diberikan terapi kompres hangat. Dimana dalam pelaksanaannya dilakukan selama satu hari dalam waktu 15 menit.

Menurut Sudoyo (2009) terdapat beberapa faktor risiko yang berhubungan dengan osteoarthritis seperti usia, jenis kelamin, suku bangsa dan genetik, kegemukan dan penyakit metabolik, cidera sendi, pekerjaan dan olah raga. Berdasarkan data umum tentang riwayat pekrjaan menunjukan bahwa hampir sebagian (46,9\%) dari responden mempunyai riwayat pekerjaan sebagai ibu rumah tangga, dan sebagian kecil sebagai pensiunan (25\%). Pekerjaan yang terlalu lama dan berulang-ulang yang dilakukan oleh individu akan membuat individu merasakan nyeri. Lansia yang mengalami osteoarthritis yang bekerja telalu lama dan monoton akan merasakan nyeri. Data tersebut sesuai dengan teori tentang respons nyeri yang di kemukakan oleh (Hidayat, 2006) dalam (Prasetyo, 2010) bahwasanya keletihan dan aktifitas serta pengalaman sebelumnya sangat mempengaruhi skala nyeri yang di alami oleh lansia.

Penurunan tingkat nyeri yang terjadi setelah diberikan terapi kompres panas sesuai dengan mekanisme Gate Control Theory oleh Melzack dan Wall (1965), yang menyatakan bahwa impuls nyeri dihantarkan saat sebuah pertahanan dibuka dan impuls dihambat saat pertahanan ditutup. Upaya menutup pertahanan tersebut terjadi saat dilakukan kompres panas yang dapat menghambat impuls nyeri yang akan disampaikan ke otak untuk dipersepsikan.

Kompres hangat merupakan salah satu pengobatan non farmakologi yang dapat membantu meredakan rasa nyeri, kaku dan spasme otot. Efek fisiologis terapi panas terhadap hemodinamik mampu meningkatkan aliran darah, vasodilatasi meningkatkan penyerapan nutrisi, leukosit dan anti bodi dan meningkatkan pembuangan sisa metabolik dan sisa jaringan sehingga membantu resolusi kondisi inflamasi (Chandra, 2002). Penggunaan terapi panas pada permukaan tubuh dapat memperbaiki fleksibilitas tendon dan ligament, mengurangi spasme otot, meredakan nyeri, meningkatkan aliran darah dan metabolisme (Wachjudi, dkk. 2006). Terapi panas yang dilakukan dapat menggunakan kompres hangat. Kompres tersebut dapat memberikan efek fisiologis dengan meningkatkan relaksasi otot pergerakan sendi (Rifham, 2010). Mekanismenya dalam mengurangi nyeri tidak diketahui dengan pasti walaupun para peneliti yakin bahwa panas dapat menonaktifkan serabut saraf, melepaskan endorphin, opium yang sangat kuat yang dapat memblok transmisi nyeri (Kozier \& Erb's, 2009).

Berdasarkan hasil penelitian sebelumnya oleh Noorhidayah, dkk (2013) 
juga mengatakan bahwa sebelum diberikan kompres panas, pasien lansia dengan nyeri rematik di PSTW Budi Sejahtera Provinsi Kalimantan Selatan yang mengalami nyeri ringan sebanyak $7,70 \%$, nyeri sedang sebanyak $57,69 \%$, dan nyeri berat terkontrol sebanyak $34,61 \%$. Sesudah diberikan terapi kompres panas, pasien lansia dengan nyeri rematik di PSTW Budi Sejahtera Provinsi Kalimantan Selatan yang mengalami nyeri ringan sebanyak $57,69 \%$, dan nyeri sedang sebanyak $42,31 \%$. Pemberian terapi kompres panas pada lansia dengan nyeri rematik di PSTW Budi Sejahtera Provinsi Kalimantan Selatan berpengaruh secara bermakna terhadap penurunan tingkat nyeri $(p=0,000)$.

Hasil penelitian ini juga sesuai dengan hasil penelitian Ani Dwi Pratintya (2014) dengan judul "Kompres Hangat Menurunkan Nyeri Persendian Osteoarthritis Pada Lanjut Usia" dengan nilai rata-rata tingkat nyeri sebelum diberikan kompres hangat pada kelompok kontrol sebesar 5,5 dan pada kelompok eksperimen sebesar 5,25. Nilai rata-rata nyeri sesudah diberikan kompres hangat pada kelompok kontrol menjadi 4,3 dan pada kelompok eksperimen menjadi 1,25 . Terdapat perbedaan penurunan tingkat nyeri sebesar 1,16 pada kelompok kontrol dan sebesar 4,00 pada kelompok eksperimen. Hal tersebut menunjukkan terdapat penurunan tingkat nyeri persendian osteoarthritis pada lanjut usia setelah diberikan perlakuan berupa kompres hangat.

Pada praktiknya, kegiatan terapi kompres hangat merupakan serangkaian teknik terapi untuk merangsang area-area tertentu diatas lutut dengan tujuan menimbulkan respons yang bermanfaat bagi bagian tubuh yang lain. Kompres hangat dapat digunakan untuk terapi pada penderita nyeri sendi, hal ini disebabkan karena adanya stimulasi yang digunakan untuk mengurangi nyeri persendian.

\section{Pengaruh Kompres Hangat Terhadap Nyeri Sendi Osteoarthritis Pada Lansia}

Berdasarkan penelitian menujukkan bahwa setelah diberikan intervensi terapi kompres hangat sebagian besar lansia mengalami penurunan skala nyeri.

Efek penuaan dan efek mekanis menjadi salah satu penyebab utama nyeri sendi pada lansia. Menurut Felson (2008), nyeri sendi yang paling umum dialami lansia yaitu nyeri kronik. Lansia yang mengalami nyeri kronik seringkali mengalami periode remisi (gejala hilang sebagian atau keseluruhan) dan eksaserbasi (keparahan meningkat). Sifat nyeri kronik yang tidak dapat diprediksi ini membuat klien frustasi dan seringkali mengarah pada depresi psikologi. Penyebabnya mungkin diketahui progresif atau persisten atau tidak diketahui bahkan sulit untuk ditemukan. Lansia tersebut cenderung mengalami ketidakmampuan akibat nyeri yang sedang dirasakan. Nyeri kronik yang paling umum diderita oleh lansia yaitu nyeri sendi yang sifatnya degeneratif yang sering disebut dengan nyeri sendi osteoarthritis. Nyeri sendi ini merupakan penyakit degeneratif dengan etiologi dan pathogenesis yang belum jelas serta mengenai populasi yang luas (Joern, Klaus, \& Peer, 2010 dalam Nugroho, 2008). Gambaran mendasar pada nyeri sendi ini adalah degenerasi tulang rawan sendi yaitu perubahan struktural selanjutnya yang terjadi di tulang bersifat sekunder (Martono \& Pranaka, 2009). Pada sebagian besar kasus, penyakit ini muncul tanpa faktor predisposisi yang jelas sehingga disebut primer. Sebaliknya, nyeri sendi sekunder adalah perubahan degeneratif yang terjadi pada sendi yang sudah mengalami deformitas, atau degenerasi sendi yang terjadi dalam konteks penyakit metabolik tertentu, seperti hemokromatis atau diabetes melitus. Respon seseorang terhadap nyeri dipengaruhi oleh emosi, tingkat kesadaran, latar belakang budaya, pengalaman masa lalu tentang nyeri dan pengertian nyeri (Davey, 2005). Nyeri mengganggu kemampuan seseorang untuk beristirahat, konsentrasi dan kegiatankegiatan yang biasa dilakukan.

Stimulasi kutaneus adalah stimulasi kulit yang digunakan untuk menghilangkan nyeri. Seperti masase, mandi air hangat dan kompres dingin merupakan langkah sederhana dalam upaya menurunkan nyeri. Cara kerja stimulasi kutaneus adalah adanya pemikiran bahwa pelepasan endorfrin sehingga transmisi stimulasi nyeri terblokade. Tindakan stimulasi kulit seperti kompres hangat dan dingin ini disebutkan dapat menurunkan tingkat nyeri (Crisp \& Taylor, 2005).

Menurut Price (1995), kompres hangat sebagai metode yang sangat efektif untuk mengurangi nyeri atau kejang otot. Panas dapat disalurkan melaui konduksi (botol air panas). Panas dapat melebarkan pembuluh darah dan dapat meningkatkan aliran darah. Secara biologi efek pemberian 
terapi kompres hangat pada daerah tubuh akan memberikan sinyal ke hipotalamus melalui sumsum tulang belakang. Ketika reseptor yang peka terhadap panas di hipotalamus dirangsang, sistem efektor mengeluarkan sinyal yang memulai berkeringat dan vasodilatasi perifer. Perubahan ukuran pembuluh darah diatur oleh pusat vasomotor pada medulla oblongata dari tangkai otak, dibawah pengaruh hipotalamus bagian anterior sehingga terjadi vasodilatasi. Terjadinya vasodilatasi ini menyebabkan aliran darah ke setiap jaringan, dan akan terjadi penurunan ketegangan otot sehingga nyeri sendi yang dirasakan pada penderita osteoarthritis dapat berkurang bahkan menghilang. Kompres hangat juga berfungsi untuk melancarkan pembuluh darah sehingga dapat meredakan nyeri dengan mengurangi ketegangan, menurunkan kontraksi otot, meningkatkan aliran darah daerah persendian dan meningkatkan rasa nyaman. Panas dapat menyebabkan dilatasi pembuluh darah yang mengakibatkan peningkatan sirkulasi darah. Secara fisiologis respon tubuh terhadap panas yaitu pelebaran pembuluh darah, menurunkan suhu tubuh, menurunkan kekentalan darah, menurunkan ketegangan otot, meningkatkan metabolisme jaringan dan meningkatkan permeabilitas kapiler. Respon dari tubuh inilah yang digunakan untuk keperluan terapi pada berbagai kondisi dan keadaan yang terjadi dalam tubuh (Potter \& Perry, 2005).

Kompres hangat dapat digunakan sebagai alat terapi nyeri sendi untuk menghilangkan rasa sakit yang dialami oleh pasien osteoarthritis, dimana rasa hangat bisa merelaksasikan dan melancarkan peredaran darah ke seluruh tubuh sehingga dapat mengurangi ketegangan dan menimbulkan rasa nyaman. Efektifitas kompres hangat meningkatkan aliran darah untuk mendapatkan efek analgesik dan relaksasi otot sehingga proses inflamasi berkurang (Lemone \& Burke, 2001). Pengompresan yang dilakukan dengan menggunakan bulibuli panas yang dibungkus kain yaitu secara konduksi dimana terjadi pemindahan panas dari buli-buli ke dalam tubuh sehingga akan menyebabkan pelebaran pembuluh darah dan akan terjadi penurunan ketegangan otot sehingga nyeri yang dirasakan akan berkurang atau hilang (Perry \& Potter, 2005).

Kompres hangat bertujuan melebarkan pembuluh darah dan mereggangkan ketegangan otot pada bagian yang terasa nyeri. Tujuan dari kompres hangat adalah pelunakan jaringan fibrosa, membuat otot tubuh lebih rileks, menurunkan rasa nyeri, dan memperlancar pasokan aliran darah dan memberikan ketenangan pada klien (Azril Kimin, 2009). Kompres hangat juga berfungsi untuk melebarkan pembuluh darah, menstimulasi sirkulasi darah, dan mengurangi kekakuan. Selain itu, kompres hangat juga dapat menghilangkan sensasi rasa sakit. Menurut Hegner (2003) efek dari kompres air hangat dapat dibagi menjadi tiga, yaitu efek secara fisik, kimia dan biologis. Efek fisik dengan cara transfer panas yang diberikan melalui kompres air hangat sehingga menyebabkan zat cair, padat dan gas memuai ke segala arah. Efek kimia pemberian kompres air hangat yaitu meningkatkan metabolisme sel tubuh. Efek biologis yang dapat terjadi ketika diberikan kompres air hangat adalah peningkatan sirkulasi darah dan peningkatan tekanan kapiler. Tekanan $\mathrm{O} 2$ dan $\mathrm{CO} 2$ di dalam darah akan meningkat sedangkan $\mathrm{pH}$ darah akan mengalami penurunan. Menurut Kozier dalam Suprapti (2008) mengungkapkan bahwa panas mempunyai efek yang berbeda dalam tubuh, efek tersebut juga tergantung dari lamanya pemberian panas. Pemberian panas $15-30$ menit memiliki efek vasodilatasi pembuluh darah sehingga terjadi peningkatan aliran darah. Peningkatan aliran darah akan menurunkan viskositas darah dan metabolisme lokal karena aliran darah membawa oksigen ke jaringan.

Stimulasi kulit mengaktifkan transmisi serabut saraf sensori A-beta yang lebih besar dan lebih cepat. Proses ini menurunkan transmisi nyeri melalui serabut $C$ delta- $A$ berdiameter kecil. Gerbang sinap menutup transmisi impuls nyeri. Kompres menggunakan air hangat akan meningkatkan aliran darah, dan meredakan nyeri dengan menyingkirkan produk-produk inflamasi, seperti bradikinin, histamin dan prostaglandin yang menimbulkan nyeri lokal. Panas akan merangsang serat saraf yang menutup gerbang sehingga transmisi nyeri ke medulla spinalis dan ke otak dihambat. Hal tersebut disebabkan karena setelah 15 menit pemberian kompres hangat pada daerah tubuh akan memberikan sinyal ke hipotalamus melalui sumsum tulang belakang. Ketika reseptor yang peka terhadap panas di hipotalamus dirangsang, sistem efektor mengeluarkan sinyal yang memulai berkeringat dan vasodilatasi perifer. 
Perubahan ukuran pembuluh darah diatur oleh pusat vasomotor pada medulla oblongata dari tungkai otak, di bawah pengaruh hipotalamik bagian anterior sehingga terjadi vasodilatasi. Terjadinya vasodilatasi ini menyebabkan aliran darah ke setiap jaringan khususnya yang mengalami radang dan nyeri bertambah sehingga mengalami penurunan skala nyeri pada jaringan yang meradang (Potter \& Perry, 2005).

Penelitian ini juga mendukung teori bahwa kompres hangat merupakan salah satu metode efektif untuk mengurangi nyeri sendi (Potter, Patricia, \& Anne, 2005). Kompres hangat yang disalurkan melalui konduksi seperti kantong karet yang diisi air hangat atau dengan buli-buli panas atau handuk yang telah direndam dengan air hangat ke bagian tubuh yang nyeri dengan suhu air sekitar 37$40^{\circ} \mathrm{C}$ karena pada suhu tersebut kulit dapat mentoleransi sehingga tidak terjadi iritasi dan kemerahan pada kulit yang dikompres (Kozier \& Erb's, 2009).

Berdasarkan penelitian sebelumnya yang dilakukan oleh Yohana, dkk (2017) dengan judul "Perbedaan Intensitas Nyeri Osteoartritis Pada Lansia Sebelum Dan Sesudah Dilakukan Kompres Hangat Di Kelurahan Tlogomas Malang" di dapat data hasil uji statistik yaitu Peired Simple T-Test dengan teknik komputerisasi dengan tingkat signifikasi (a) sebesar 0,05 dan tingkat kesalahan $95 \%$. Hasil perhitungan di dapat $P$ value $=0,00<\alpha(0,05)$ yang berarti $\mathrm{HO}$ ditolak. Hasil yang didapat peneliti ada perbedaan intensitas nyeri osteoartritis pada lansia sebelum dan sesudah dilakukan kompres hangat di Kelurahan Tlogomas RT 02 RW 06 Malang. Usia pertengahan cenderung akan mengalami penurunan aktifitas dan berlanjut sampai tua karena terjadinya penurunan fungsi tubuh akibat proses penuaan. Organ-organ tubuh yang dulunya berfungsi dengan baik tanpa adanya gangguan, sekarang mengalami kemunduran karena dalam proses penuaan.

Menurut penelitian yang dilakukan oleh Mellynda, dkk (2014) dengan judul "Pengaruh Kompres Hangat Terhadap Penurunan Skala Nyeri Pada Penderita Gout Arthritis Di Wilayah Kerja Puskesmas Bahu Manado", didapatkan hasil uji statistik ada pengaruh pemberian kompres hangat terhadap penurunan skala nyeri pada penderita gout arthritis di Wilayah Kerja Puskemas Bahu Manado. Nyeri gout arthritis pada responden sebelum diberikan kompres hangat yaitu didapatkan sebagian besar responden berada pada tingkat nyeri berat. Nyeri gout arthritis pada responden sesudah diberikan kompres hangat yaitu didapatkan sebagian besar responden berada pada tingkat nyeri ringan.

Hasil penelitian ini juga sesuai dengan hasil penelitian Sinaga, dkk (2015) dengan judul "Pengaruh Kompres Hangat Terhadap Penurunan Nyeri Sendi Pada Lansia (60-74 Tahun)" dengan selisih nilai rata-rata nyeri sendi lansia setelah perlakuan pada kelompok kontrol dan kelompok intervensi. Hasil uji menunjukkan selisih mean pada kelompok intervensi lebih tinggi yaitu sebesar 2,200 dibanding dengan kelompok kontrol dengan selisish mean 0,466 yang artinya penurunan skal nyeri sendi lansia pada kelompok intervensi jauh lebih tinggi dibanding kelompok kontrol. Hasil uji menunjukkan saat pengukuran kedua ada perbedaan skala nyeri dalam kelompok kontrol dan kelompok intervensi. Hal ini menunjukkan terdapat penurunan nyeri sendi secara signifikan baik pada kelompok kontrol maupun intervensi, tetapi pada kelompok intervensi penurunan nyeri sendi lebih besar dibandingkan kelompok kontrol.

Dari hasil penelitian di Posyandu Puskesmas Pandian Sumenep dalam memberikan perlakuan terapi kompres hangat pada lanjut usia penderita osteoarthritis terlihat terjadi penurunan intensitas skala nyeri, ini dikarenakan kompres hangat dapat melancarkan sirkulasi darah, menghilangkan rasa sakit atau nyeri, dan memberikan ketenangan serta kenyamanan. Kompres hangat merupakan salah satu terapi modalitas dalam intervensi keperawatan yang dapat digunakan untuk meningkatkan rasa nyaman pada lansia dengan nyeri sendi. Pengobatan non farmakologi sangat efektif dilakukan untuk mengurangi rasa nyeri yang timbul. Berdasarkan hasil penelitian ini, responden dapat menggunakan terapi kompres hangat ini sebagai salah satu pilihan terapi non farmakologi dalam menangani nyeri sendi.

\section{KESIMPULAN DAN SARAN \\ Kesimpulan}

Dari hasil penelitian tentang pengaruh terapi kompres hangat terhadap penurunan nyeri sendi osteoarthritis pada lansia di posyandu lansia Puskesmas Pandian Sumenep, dapat diambil kesimpulan sebagai berikut: 
1. Tingkat nyeri pada pasien sebelum diberikan kompres hangat sebagian besar responden mengalami tingkat nyeri sedang dengan skala 4-6.

2. Tingkat nyeri pada pasien sesudah diberikan kompres hangat sebaian besar responden mengalami tingkat nyeri ringan dengan skala 1-3.

3. Ada pengaruh yang signifikan antara kompres hangat dengan kejadian tingkat nyeri pada pasien dengan osteoarthitis di posyandu lansia Puskesmas Pandian Sumenep.

\section{Saran}

1. Bagi Pelayanan Kesehatan

Diharapkan penelitian ini dapat dijadikan sebagai intervensi mandiri keperawatan dalam menangani pasien nyeri sendi dengan osteoarthritis di Rumah Sakit maupun di pelayanan kesehatan lainnya.

2. Bagi Keluarga Pasien

Perlu diberikan pengetahuan tentang penanganan terhadap nyeri secara mandiri guna meminimalkan penggunaan terapi farmakologi

3. Bagi Akademik

Pada pihak akademik diharapkan dapat meningkatkan keterampilan mahasiswa dalan penerapan penyuluhan kesehatan terutama pada pasien osteoarthritis

4. Bagi Profesi

Diharapkan penelitian ini dapat digunakan sebagai salah cara dalam meningkatkan kualitas hidup lanjut usia sehingga dapat menjadi usia lanjut yang berguna dan bahagia

5. Bagi Peneliti Selanjutnya

Diharapkan penelitian ini dapat digunakan sebagai masukan bagi peneliti selanjutnya untuk mengadakan penelitian lebih lanjut tentang Pengaruh Kompres Hangat Terhadap Penurunan Nyeri Sendi Osteoarthritis Pada Lansia dan dilakukan penelitian lebih lanjut dengan metode penelitian yang berbeda, variabel yang berbeda, perlakuan yang lebih sering, kombinasi kompres, jumlah populasi dan sampel yang lebih banyak sehingga akan diperoleh hasil yang lebih baik.

\section{DAFTAR PUSTAKA}

Andarmoro, Sulistyo. 2013. Konsep dan Proses Keperawatan Nyeri. Yogyakarta. Ar-Ruzz Media.
Asmadi. 2008. Konsep dan Aplikasi Kebutuhan Dasar Klien. Jakarta. Salemba Medika.

Alimul, Hidayat. 2003. Riset Keperawatan dan Teknik Penulisan IImiah Edisi I. Jakarta. Salemba Medika.

Alimul, Hidayat. 2010. Metode Penelitian Kesehatan paradigma kuantitatif. Jakarta. Salmba Medika.

Azril, Kimin, 2009. Kompres Alternatif Pereda Nyeri, http://luluvikar.wordpress.com/2009/0 8/26/persepsi-ibu-tentang-metode diakses 9 Desember 2017 pukul 18.52 WIB.

Baughman, Diane C., Hackley, Joann C. 2000. Keperawatan Medikal Bedah Buku Saku dari Brunner \& Suddarth. Jakarta. EGC.

Chandra, A.S. 2002. Perbandingan Efek Terapi Panas Dengan Terapi Dingin Terhadap Pengurangan Nyeri Pada Penderita Osteoartritis Lutut Di Instalasi Rehabilitasi Medik RSUP DR.Kariadi Semarang. Program Studi Rehabilitasi Medik, Fakultas Kedokteran Universitas Diponegoro, Semarang.

Churlish. (2009). Jawaban-Jawaban Alternatif Untuk Arthritis Dan Rheumatic. Yogyakarta: Citra Adi Pratama.

Crisp, J., \& Taylor, C. (Eds.). (2005). Potter and Perry's fundamentals of nursing (2nd ed.). Sydney: Mosby.

Davey, P. 2005. At a glance medicine. Jakarta : Erlangga.

Davies, Kim. 2007. Buku Pintar: Nyeri Tulang dan Otot. Jakarta. Erlangga

Deu, Rita Purnama, dkk. 2014. Gambaran Kejadian Nyeri Lutut Dengan Kecurigaan OsteoartritisLlutut Pada Perawat Di Poliklinik Rawat Jalan Blu RSUP. Prof. Dr. R. D. Kandou manado.

https://ejournal.unsrat.ac.id/index.php /eclinic/article/download/3859/3374. diakses tanggal 24 Mei 2018 pukul 11.08 WIB

Dewi, Sofia Rhosma. 2014. Buku Ajar Keperawatan Gerontik. Yogyakarta. Deepublish.

Efendi, Ferry., Makhfudli. 2009. Keperawatan Kesehatan Komunitas. Jakarta. Salemba Medika.

Faizal, Yatim. 2006. Penyakit Tulang dan Persendian. Jakarta. Pustaka Populer Obor. 
Gottlieb, B. H. 1983. Social Support Strategies : Giddelines for Mental Helth Practice. London. Sage Publication.

Hartono, Andry. 2006. Terapi Gizi dan Diet Rumah Sakit Edisi 2. Jakarta. EGC.

Hashmi, Syed Musad Rahim., Fatima, Lubna. 2011. Treatment of Osteoarthritis Knee. New Delhi-India. Jaypee Brothers Medical Publishers (P) LTD.

Hegner, Barbara R. 2013. Asistensi Keperawatan Suatu Pendekatan Proses Keperawatan. Jakarta : EGC.

Kawiyana, I. K. S. 2009. Osteoporosis Patogenesis Diagnosis dan Penanganan Terkini. Jurnal Penyakit Dalam, 10: 157-170.

Kolcaba K. et al. (2006). Comfort Theory: $A$ Unifying Framwork to Enchance the Practice Environment. JONA Vol. 36 Number 11, Pp 538-544 2006. Lippincott William \& Wilkins inc.

Kozier, B. \& Erb, G. 2009. Buku Ajar Praktik Keperawatan klinis. Edisi 5. Jakarta. EGC.

Kuntono, Heru Purbo. 2007. Patofisiologi Nyeri dan Aspek Fisiologi dari Aspek Nyeri. Surakarta.

Kusyati. 2006. Keperawatan Dasar. Jakarta. ECG.

Martono, H.H., \& Pranaka K. 2009. Geriatry (IImu kesehatan usia Lanjut). Ed 4. Jakarta. FKUI.

Masyhurrosyidi, dkk. 2014. Pengaruh Kompres Hangat Rebusan Jahe Terhadap Tingkat Nyeri Subakut dan Kronis pada Lanjut Usia dengan Osteoarthtritis Lutut di Puskesmas Arjuna Kecamatan Klojen Malang Jawa Timur. http://majalahfk.ub.ac.id/index.php/m $\mathrm{kfkub} / \mathrm{article} / \mathrm{view} / 21$. diakses tanggal 04 Februari 2018 pukul 13.55 WIB.

Mellynda, dkk. 2014. Pengaruh Kompres Hangat Terhadap Penurunan Skala Nyeri Pada Penderita Gout Arthritis Di Wilayah Kerja Puskesmas Bahu Manado.

https://www.neliti.com/id/publications/ 112565/pengaruh-kompres-hangatterhadap-penurunan-skala-nyeripada-penderita-gout-arthr. diakses tanggal 14 November 2017 pukul 19.22 WIB.

Melzack, R., dan Wall, P. D. 1965. Pain Mechanism : A New Theory : Science $150: 971-979$.
Muhitt, Abdul \& Siyoto, Sandu. 2016. Pendidikan Keperawatan Gerontik. Yogyakarta. Andi Offset.

Muttaqin, Arif. 2008. Asuhan Keperawatan Klien dengan Gangguan Sistem Persarafan. Jakarta. Salemba Medika.

Noorhidayah, dkk. 2013. Terapi Kompres Hangat Terhadap Penurunan Tingkat Nyeri Klien Lansia Dengan Nyeri Rematik..

http://ppjp.unlam.ac.id/journal/index.p $\mathrm{hp} / \mathrm{JDK} /$ article/download/1656/1430. diakses tanggal 14 November 2017 pukul 19.23 WIB.

Nursalam. 2003. Konsep \& Penerapan Metodologi Penelitian IImu Keperawatan: Pedoman Skripsi, Tesis, dan Instrumen Penelitian Keperawatan. Jakarta. Salemba Medika.

Nursalam. 2008. Konsep dan Penerapan Metodologi Penelitian IImu Keperawatan. Jakarta. Salemba Medika.

Nursalam. 2013. Metodologi Penelitian IImu Keperawatan: Pendekatan Praktis. Edisi 3. Jakarta. Salemba Medika.

Nursalam dan Pariani, S. 2001. Pendekatan Praktis Metodologi Riset Keperawatan. Jakarta. Salemba Medika.

Partojo, Slamet. 2002. Assesment Fisioterapi pada Sendi Lutut. Tema IImiah Tahunan Fisioterapi (TIT AFI) XX Semarang.

Pratintya, Ani Dwi. 2012. Pengaruh Pemberian Kompres Hangat Terhadap Nyeri Persendian Ostoartritis pada Lanjut Usia di Panti Wredha Budhi Dharma Ponggalan Umbulharjo Yogyakarta, http://digilib.unisayogya.ac.id/719/1/N ASKAH\%20PUBLIKASI_ANI\%20DWI \%20PRATINTYA\%20\%28080201026 \%29.pdf diakses tanggal 14 November 2017 pukul 19.22 WIB.

Potter \& Perry. 2005. Buku Ajar Fundamental Keperawatan Volume 2. Jakarta. EGC.

Potter \& Perry. 2006. Buku Ajar Fundamental Keperawatan. Edisi 4. Jakarta : EGC.

Price, Sylvia. A, Lorraine, M. Wilson. (1995). Buku 1 Patofisiologi "Konsep Klinis Proses-Proses Penyakit", edisi : 4. Jakarta : EGC. 
Risnanto., Insani, Uswatun. 2014. Buku Ajar Asuhan Keperawatan Medikal Bedah (Sistem Yogyakarta. Deepublish.

Riyanto, Agus. 2011. Aplikasi Metodologi Penelitian Kesehatan. Yogyakarta: Nuha Medika.

Santoso, Hanna., Anda, Ismail. 2009. Memahami Krisis Lanjut Usia. Jakarta. Gunung Mulia.

Setiadi, 2013. Konsep dan Praktikum Penulisan Riset Keperawatan Edisi 2. Yogyakarta. Graha IImu.

Sinaga, Henricha Evalina., Ropyanto, Chandra Bagus. 2015. Pengaruh Kompres Hangat Terhadap Nyeri Sendi Pada Lansia (60-74 Tahun). http://eprints.undip.ac.id/46654/1/Pro ceeding_Semilnaskes_2015_Chandr a.pdf diakses tanggal 14 November 2017 puku 19.23 WIB

Siti Maryam. R., dkk. 2008. Mengenal Usia Lanjut dan Perawatannya. Jakarta. Salemba Medika.

Steven, dkk. 2002. IImu Keperawatan. Cetakan pertama. Jakarta. EGC.

Sudoyo. 2006. IImu Penyakit Dalam Jilid III. Jakarta: EGC.

Uliyah, Musrifatul., Hidayat, Aziz Alimul. 2008. Praktikum Keterampilan Dasar Praktik Klinik: Aplikasi Dasar-dasar Praktik Kebidanan. Jakarta. Salemba Medika.

Wachjudi, dkk. 2006. Diagnosis dan Terapi Penyakit Reumatik. Jakarta. CV. Sagung Seto.

Wulan, Rifda Angelina. 2015. Pengaruh Terapi Kompres Air Hangat Terhadap Penurunan Skala Nyeri Sendi Pada Wanita Lanjut Usia Di Panti Tresna Werdha Mulia Dharma Kabupaten Kubu Raya. http://jurnal.untan.ac.id/index.php/jmk eperawatanFK/article/view/9438.

diakses tanggal 14 November 2017 pukul 19.23 WIB.

Yuliastri, Aminurul. 2012. Pengaruh Kompres Panas Dan Kompres Dingin Terhadap Pengurangan Nyeri Pada Osteoarthritis Sendi Lutut, http://eprints.ums.ac.id/21943/17/02. NASKAH_PUBLIKASI.pdf diakses tanggal 6 Februari 2018 pukul 15.01 WIB.

Yohana, dkk. 2017. Perbedaan Intensitas Nyeri Osteoartritis Pada Lansia Sebelum Dan Sesudah Dilakukan
Kompres Hangat Di Kelurahan Tlogomas Malang. https://publikasi.unitri.ac.id/index.php/ fikes/article/download/185/219. diakses tanggal 26 Maret 2018 pukul 13.41 WIB. 
